\title{
THE CROWN OF HUNGARY BEFORE AND AFTER THE HUNGARIAN CROWNING: THE USE OF THE HOLY CROWN OF HUNGARY IN HUNGARIAN REVOLTS AND HABSBURG REPRESENTATION BETWEEN 1604 AND 1611
}

\author{
KEES TESZELSZKY \\ National Library of The Netherlands \\ teszelszky@gmail.com
}

\begin{abstract}
This study deals with the use of the Holy Crown of Hungary in Hungarian revolts and Habsburg representation between 1604 and 1611. It describes how the meaning of the crown suddenly changed after 1604 and how this meaning was spread across the borders of Hungary. The focus is on the use of the crown in the propaganda of King Matthias II at the time of his crowning as King of Bohemia in 1611. This is a rare example of the use of the Hungarian crown in the political legitimation of a ruler in another country outside Hungary, but it has a special ideological background. This use is an aspect of the history of the crown that has been overlooked to this day.
\end{abstract}

Keywords: Political thought, political and national identities, coronations, propaganda, representation

The Holy Crown of Hungary is not only one of the oldest crown jewels of the world, it is also one loaded with a heavy symbolic meaning. This meaning is not confined to the crowning ceremony or the Hungarian kingship itself, like other medieval crowns in Europe. This object, also known as Saint Stephan's crown, is one of the most widely used and venerated symbols of modern Hungarian nationalism, but has also been present for ages in the political culture of Hungary as well. This has not always been like this: sometimes the crown was tucked away in its metal chest and no one bothered it. But as political tensions rose in the kingdom of Hungary or the society was in turmoil, the crown came virtually out of its chest and was used as expression of political ideas and as legitimation of power of a certain person or group or embodied an idea. The sudden use of the crown did influence culture like throwing a stone in a pond: the development of this crown culture did not stop at the borders of the Hungarian kingdom, but spread as shock waves across Europe.

I will describe in this study how the meaning of the crown suddenly changed after 1604 and how this meaning was spread across the borders of Hungary. The most significant development of the meaning of the crown in Hungary took 
place between 1604 and 1608 during the so-called Bocskai revolt (1604-1606), the Bruderzwist between Emperor Rudolf II and Archduke Matthias and the crowning of Archduke Matthias as King Matthias II of Hungary in November 1608. Moreover, the crown was also used during the propaganda of King Matthias II at the time of his crowning as King of Bohemia in 1611. This use is an aspect of the history of the crown that was overlooked till this day.

To understand the role and function of the crown in the discourse around the crown, a certain amount of background information on the meaning of this crown is essential. References to the crown in early modern Hungary can be understood in three different senses: the visible crown, the invisible crown, and the tradition or cult of the Holy Crown (Kantorowicz, 1958, Péter, 2003. 421-510, Teszelszky, 2009).

The "visible crown" refers to the crown as a tangible object made of gold and precious stones. In Hungary, a tangible crown of Saint Stephen, used by the members of the first Árpád dynasty (1000-1301) as coronation crown, was already referred to in the 13th century as the "Holy Crown of Hungary".

The "invisible crown" denotes the royal power or authority of the king of Hungary. This power is transferred on him exclusively by coronation with the Holy Crown, and only with the prior consent of the Hungarian estates. The "invisible crown" and the notion of kingship were frequently used as interchangeable notions in legal documents in Hungary.

The "cult of the Holy Crown" or the "tradition of the Holy Crown" refers to the legitimation of royal power, the liberties of the estates, or any other idea in the political community using any reference to the Holy Crown in word or image. The cult rooted in the tangible crown and its history and meaning, but was developed by anyone in Hungary who had political aspirations. The king did want to keep this cult in his power sphere, but many times the cult or the tradition of the Holy Crown was used against the person who was crowned by the tangible crown. The crown cult was thus used to undermine the power of the invisible crown of the king.

The "tradition of the Holy Crown" is as such one of the special features of the political culture of the Kingdom of Hungary. It can even be considered as an unique phenomenon in Europe: there is no other crown jewel which is venerated in the way the Hungarian crown is. Its cult lives on, even without a legitimate ruler and even when the kingdom ceased to exist. It refers to all the ways in which the crown was used in history to legitimate anything political. The way this legitimation was coined in text or image had a strong religious sense, which is not exclusively tied to the Catholic religion: also Hungarian Lutherans and even Calvinists could venerate the crown.

The tradition is historically strongly related to the power of the estates in the kingdom versus the authority of their ruler. As the Hungarian estates gained in 
strength in relation to their chosen king at the end of the Medieval period, so the tradition of the Holy Crown became more developed. At the same time, the ruler tried to master its own invisible crown by developing the crown tradition in favour of royal authority. As such, the tradition is strongly connected with the notion of the visible and the invisible crown. The tradition of the Holy Crown gained in strength after the death of the last member of the Árpád dynasty in 1301 and reached its height at the end of the Medieval period and the reign of King Matthias Corvinus (1458-1490). The crown tradition was described in detail by Antonio Bonfini in his magnum opus on the history of Hungary, which was only published in 1568. Many images of the crown were made and used to develop the crown cult from the end of the $16^{\text {th }}$ century.

The most famous work containing a reference to the tradition of the crown dates from 1514, when the leading judge at the royal court and political leader of the party of the nobility, István Werböczy (1458?-1541), completed his Hungarian law-book. It was printed in 1517 and reprinted many times afterwards, but was never ratified by the Habsburg king. According to him, all members of the nobility "enjoy one and the same liberty" (una eademque libertatem gaudent), since their rights have the same origin: bestowed on them from the possessions of the Holy Crown of Hungary (peculium coronae Hungariae). (Péter 2008, 45-46) The nobles have the right to oppose their king if he acts in a way that is contrary to the liberties of the nobles on the basis of the contents of the Golden Bull of King András II (1222), on which the ruler must swear during coronation with the Holy Crown.

The concepts of the nation and the Holy Crown in the work of Werböczy were reused as arguments to provide legitimacy for political power in Hungary from the end of the $18^{\text {th }}$ century. Historians and jurists in Hungary started to research the roots of their nation and the medieval history of the Holy Crown to support the claims to sovereignty on behalf of the estates against the power and authority of the Habsburg dynasty. These efforts resulted in a political ideology in which the notion of the crown and the idea of the nation were combined: the Szentkorona$\tan$ (Doctrine of the Holy Crown). (Péter, 2003, 450-452). This doctrine was only fully developed in the $19^{\text {th }}$ century.

According to the content of the doctrine, a single phrase in this work (membra sacrae coronae, "members of the Holy Crown") summarised a longstanding organic state concept of Hungary. Based on this concept, king, church and nobility divided power among themselves in the mystical body of the Holy Crown.

These three words - membra sacrae coronae - served as historic legitimation of the modern sovereignty of the Hungarian nation and are still in use in modern political language. László Péter described it thus: "It is, then, a remarkable feat of 19th-century scholarship that it was on Werböczy's authority that this metaphor, used in a single instance and in a very different context, could become the main 
evidence for evolution towards the concept of a unified system of public law and political authority." (Péter, 2003, 452). Interestingly, there is not a single source dated after 1517 in which this organic metaphor of the Holy Crown, or the phrase membra sacrae coronae, can be found. As such, the period between 1517 and the $18^{\text {th }}$ century is the most interesting part of the intellectual and cultural history of the Holy Crown.

The content of Werböczy's law-book has served since 1517 as the main source for the development of the tradition of the crown, especially after 1800 . However, a reverse movement was also possible: due to the authoritarian politics of the Habsburg emperor in the Kingdom of Hungary towards the Hungarian estates after 1572 under the rule of king Rudolf I the later Emperor Rudolf II., there were no signs of a renewal of the crown tradition in any source. In fact, there is not a single source to be found dated between 1572 and 1603 containing a reference to the tradition of the Holy Crown.

Any reference to the Holy Crown of Hungary could be used to denote the crown itself, to distinguish the Habsburg royal power in Hungary from the liberties of the estates, to legitimate the demands of the estates towards the king, and to distinguish the political culture in Hungary from the Habsburg dynastic representation.

The revival of the tradition of the Holy Crown took place not long before the start of the Bocskai Revolt in 1604. This revolt broke out because of the growing discontent on the part of the Hungarian estates towards the politics of King Rudolf I. The origin of the revival was a debate on the character of royal authority and the meaning of the crown in Hungary between the king and István Illésházy, one of the richest and most powerful magnates in the country who had a considerable political influence.

At the heart of the conflict was the question of whether the king had the right to donate his crown estates in Hungary to non-natural persons, and whether such a donation could be considered as an infringement by the king of the ius coronae regni Hungariae or the "right of the crown of the Hungarian Kingdom", as Illésházy stated. Per Rudolf, he did possess this right, based on his authority as king, crowned with the Holy Crown of Hungary. Illésházy was charged with crimen laesae maiestatis, or lèse-majesté, in 1603, due to his attack on the dignity of the king. This was the ill-famous and well documented Illésházy-case. Illésházy was stripped of his assets, which became the property of the Habsburg treasury, and had to flee the country. Meanwhile, he kept on fuelling the political debate in Hungary and influenced the gathering of the estates.

The Illésházy-case was the first occasion during the Hungarian reign of King Rudolf I (1572-1608) when the meaning of the crown had been separated from the authority of the king and thus used to limit the power of the ruler in favour of the privileges of the estates. This was a new development in the meaning of the invisible crown in disfavour of the power of the Hungarian estates. 
The discussion on the meaning of the crown continued at the beginning of the Bocskai Revolt in spring 1604 in Kassa, a town in upper Hungary. The Elisabeth Church was taken by force from the Lutherans by the Catholics, and the Lutheran pastors were removed from the town with the consent of the king. King Rudolf I used the argument that the town was peculium coronae (a possession of the crown). As the rule cuius regio, eius religio was valid in the Habsburg lands, and as the king owned the town through his Hungarian crown, he could give the church to whoever he pleased and did so if he wished.

The Hungarian estates protested this by stretching the notion of noble freedom to its utmost during the diet of Gálszécs on 26 September 1604. As the royal free towns are the property of the crown, they argued, those towns share the same degree of freedom as the nobles. As such, they cannot be considered as the property of the king, but as the property of the crown: they are pillars and members of the realm, just like the nobles. The notion of the crown was here strongly connected to the liberties of the Hungarian estates, including the royal free towns in the kingdom.

The tradition of the Holy Crown was utilised by Bocskai and the members of his court from the very outbreak of the revolt in 1604. This can be observed in letters, propagandistic writings and prints. The most significant source about the tradition of the crown was a ballad on Bocskai, written in Hungarian by János Szappanos Debreceni (Ioannes Smigmatopoeus Debrezinus) in December 1604. The text of this ballad was published in 1605 . The author was the archivist, court historian and official poet of Bocskai.

Remarkably enough, the song was written from the point of view of Bocskai's irregular troops: the Hajduk. They hail him as their leader against the unjust ruler King Rudolf I. They fight for "their fatherland" and "their crown", both of which have been trampled on by the king's forces. Bocskai's message about the crown was disseminated among the inhabitants of the kingdom through ballads such as this. The meaning of the crown, and the right to resist an unjust king, was expanded beyond the borders of the political community of the nobles to embrace all those, noble and non-noble, living in Hungary and Transylvania, who supported Bocskai in his heroic struggle against the Habsburg tyrant.

Although it was an innovative idea, we must not forget that this was written propaganda, not an official legal document. Still, it was spread by mouth and as such is an important source of how the tradition of the crown was kept alive by common people of the country. It is noteworthy though that no known image of the Holy Crown was spread at that time.

The Holy Crown of Hungary was thus invested with a new meaning during the Bocskai Revolt, as the safeguard of the liberties of the estates, the keeper of the sovereignty of the Kingdom of Hungary and the unity of Hungary and Transylvania within the boundaries of the Habsburg Empire. The political message 
of Bocskai on the liberty of Hungary was disseminated via several political declarations, which were written for various audiences in Europe between 1604 and December 1605.

Bocskai wanted to press the emperor to make peace with the Ottomans and the Hungarians and tried to obtain support from abroad to fulfil this goal. The meaning of the Holy Crown of Hungary did not yet play a significant role in these texts. This changed, however, when Bocskai requested and received a crown from the Ottomans in 1605 and the myth of the "refusal of the Turkish crown" was born. The ceremony and the creation of the myth were closely related to a new development in the tradition of the Holy Crown of Hungary.

The goal of the crown ceremony with the Ottoman crown was to reinstall the old meaning of the Hungarian crown that was undermined by King Rudolf. King Matthias II did confirm this meaning during his coronation in November 1608. His court historians Elias Berger and Iohannes Jessenius did spread this message in Europe through their books issued in 1608 and 1609.

Both authors did write down a different message, but with the same goal in mind: to legitimate the rule of Matthias. Berger did paint a picture of King Matthias that had to comfort the Catholics in Hungary and elsewhere that their rights would not be violated. The message of Jessenius was that King Matthias II could be a promising ruler elsewhere, who would guarantee the rights of the Protestant estates in the Habsburg countries.

After the crowning of Rudolf I as king of Hungary, the crown was tucked away in its iron chest and not used anymore by the ruler in his political legitimation. Matthias II did otherwise: the Holy Crown of Hungary was his main symbol of his power and good intentions as a future ruler of Protestant lands. With using this symbol, he also differentiated himself from his brother Rudolf.

It is remarkable that in many of the pamphlets, books and prints that were issued before, during and after the crowning of Matthias as king of Bohemia on 23 May 1611 the Holy Crown of Hungary and other Hungarian symbols are still being used. King Matthias even wears a Hungarian garment on his official crowning portrait as king of Bohemia.

The Bohemian court historian of Matthias, Jiri Zaveta ze Zavetic (or Georg Zawieta von Zawietitz, 1575-1637) published several important works on this view after the Bohemian crowning of Matthias in 1611. Little is known about this author: he died in prison after he took part in the Bohemian Revolt (16181620). In almost all these works a portrait of King Matthias can be found, wearing a Hungarian garment. On all the portraits, King Matthias is depicted with the Hungarian and Bohemian armour. The Hungarian armour is crowned by the Holy Crown of Hungary. This is a very rare example of the use of the Hungarian crown in the political legitimation of a ruler in another country outside Hungary. 
The clue of this use of the crown by Zaveta can be found in another little known work of the Habsburg court historian of Matthias, Elias Berger. He wrote a work on the Connubium or "marriage" between Hungary and Bohemia, which was personified by the crowning ceremony of King Matthias as king of Hungary in 1608 and king of Bohemia in 1611. Both countries are unified by one person and will have a harmonic and peaceful future together. It is thus obvious that the symbols of both countries are used by one and the same ruler to express the relationship.

We have only little notion about the question how these ideas on the "marriage" between Hungary and Bohemia spread into society and if the average inhabitant of the Hungarian and Bohemian kingdom knew about these. Still, the Hungarian Museum of Applied Arts treasures a centuries old ginger bread mould, on which Matthias is depicted as King of Bohemia and Hungary, with the armour of Hungary at his left shoulder. Political legitimization did not only travel by mouth, but also through the stomach.

\section{References}

Berger, Elias, 1608. D. O. M. Jubilaeus De Origine, Errore, Et Restitutione S. Coronae Hungariae. Viennae: S.N.

Berger, Elias, 1611. Connubium Hungariae \& Bohemiae, in Serenissimo, \& Potentissimo Principe, Ac Domino D. Matthia Secundo (etc.) Praga: Schumann

Buzási, Enikő - Pálffy, Géza, 2015. Augsburg - Wien - München -Die frühesten Darstellungen der Stephanskrone und die Entstehung der Exemplare des Ehrenspiegels des Hauses Österreich. Innsbruck. Budapest: Institut für Geschichte des Forschungszentrums für Humanwissenschaften der Ungarischen Akademie der Wissenschaften.

Ernst Kantorowicz, 1958. The King's Two Bodies: A Study in Mediaeval Political Theology. Princeton: Princeton University Press

Iparmüvészeti Muzeum, Mézeskalácsforma - II. Mátyás képmásával, 1t. 2026. http://gyujtemeny. $\mathrm{imm}$. hu/gyujtemeny/mezeskalacsforma-ii-matyas-kepmasaval/6238

Jessenius, Iohannes, 1609. Coronatio: Adiecta, Regni, Regumque Pannoniae, brevis Chronographia. Viennae: Bonnoberger

Péter, László, The Holy Crown of Hungary, Visible and Invisible. SEER, 81, no. 3 (2003), 421-510

Teszelszky, Kees, 2009. Az ismeretlen korona. Jelentések, szimbólumok és nemzeti identitás. Pannonhalma: Bencés Kiadó

Zaveta ze Zavetic, Jiri, 1611. Korunowanj ... Matthyasse Krale Uherskeho etc. toho gmena druheho. Praga: Suman

Zaveta ze Zavetic, Jiri, 1611. Odjezd z Hradu Pražského Jeho milosti matyáše krále uherského a českého etc. toho jména druhého a př́jezd skrz markrabství Lužická do hlavního města Vratislavi knižectví Slezských s poznamenáním věci některých na též cestě vykonaných. Praha: Suman 